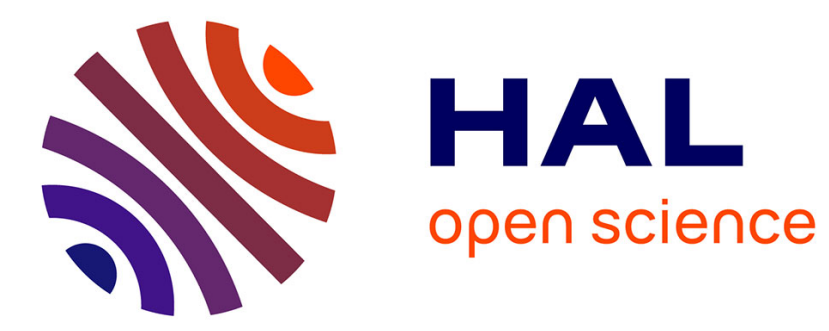

\title{
Characterization of the final stage in seed abortion in indeterminate soybean, white lupin and pea
}

Alix Pigeaire, Claude Duthion, Olivier Turc, Josette Gonthier

\section{To cite this version:}

Alix Pigeaire, Claude Duthion, Olivier Turc, Josette Gonthier. Characterization of the final stage in seed abortion in indeterminate soybean, white lupin and pea. Agronomie, 1986, 6 (4), pp.371-378. hal-00884887

\section{HAL Id: hal-00884887 https://hal.science/hal-00884887}

Submitted on 1 Jan 1986

HAL is a multi-disciplinary open access archive for the deposit and dissemination of scientific research documents, whether they are published or not. The documents may come from teaching and research institutions in France or abroad, or from public or private research centers.
L'archive ouverte pluridisciplinaire HAL, est destinée au dépôt et à la diffusion de documents scientifiques de niveau recherche, publiés ou non, émanant des établissements d'enseignement et de recherche français ou étrangers, des laboratoires publics ou privés. 


\title{
Characterization of the final stage in seed abor- tion in indeterminate soybean, white lupin and pea
}

\author{
Alix PIGEAIRE, Claude DUTHION \& Olivier TURC \\ avec la collaboration technique de Josette GONTHIER \\ I.N.R.A., Laboratoire d'Agronomie, 17, rue Sully, F 21034 Dijon Cedex
}

\begin{abstract}
A final stage in seed abortion has been identified by Japanese studies on soybcans (Glycime max (L.) Merril). It is a significant stage in the development of the yield components and it may be useful in a pod development scale. To find a simple characterization of this stage, the seeds of 26 samples of aborted plus ripe seeds at harvest were first measured and weighed. Twenty samples were of indeterminate soybean ( 10 cultivars), 4 of white lupin, Lupinus albus L. (4 cultivars), and 2 of pea, Pisum sativum L. (2 cultivars). The fact that there is no overlap of weight values between aborted seeds and ripe ones indicate that the notion of a final stage in seed abortion is of general validity for the 3 species studied. The value after which the seeds no longer abort may be slightly different between samples of different origins. Measures on green seeds sampled during crop growth were then used to determine reference lengths for green seeds corresponding to reference weights and lengths for dry ones. For the 10 soybean cultivars studied, $11 \mathrm{~mm}$ was chosen as reference length. For white lupin and pea, reference lengths were between 6 and $12 \mathrm{~mm}$, and 4 and $5.5 \mathrm{~mm}$ respectively.
\end{abstract}

Additional key words : Glycine max, Lupinus albus, Pisum sativum, stage of development, pod number, seed number.

Caractérisation du stade limite d'avortement des grains chez le soja de type indéterminé, le lupin blanc et le pois.

\begin{abstract}
Des travaux japonais déjà anciens ont mis en évidence chez le soja (Glycine max (L.) Merril) un stade limite pour l'avortement des grains. La connaissance de ce stade est utile pour décrire le développement des gousses d'une manière non pas arbitraire mais au contraire significative par rapport à la mise en place des composantes du rendement. Afin de rechercher une caractérisation simple de ce stade, des mesures de longueur et de poids ont d'abord été effectuées sur l'ensemble des grains mûrs et avortés d'échantillons prélevés à la récolte. Vingt échantillons de soja de type indéterminé (10 cultivars), 4 de lupin blanc, Lupinus albus $\mathrm{L}$. (4 cultivars), et 2 de pois, Pisum sativum L. ( 2 cultivars) ont été analysés. L'absence de chevauchement des populations de grains avortés et de grains mûrs sur les histogrammes du poids par grain montre que la notion de stade limite d'avortement des grains a une valeur générale pour les 3 espèces étudiées. La valeur caractéristique de ce stade peut varier légèrement selon la provenance de l'échantillon. Des observations en cours de végétation ont permis ensuite de déterminer les longueurs de grains verts correspondant aux longueurs et poids de référence pour les grains secs. Pour l'ensemble des 10 variétés de soja étudiées, la longueur de $11 \mathrm{~mm}$ peut être retenue comme longueur de référence. Pour le lupin blanc et le pois, les longueurs de référence appartiennent respectivement aux gammes 6-12 $\mathrm{mm}$ et $4-5,5 \mathrm{~mm}$.
\end{abstract}

Mots clés additionnels : Glycine max, Lupinus albus, Pisum sativum, stade de développement, nombre de gousses, nombre de grains.

\section{INTRODUCTION}

KATO \& SAKAgUCHI (1954) demonstrated that in soybeans (Glycine max (L.) Merril), the most developed aborted seeds had reached the beginning of the cotyledon elongation stage. According to KATO $e t$ al. (1955), the seeds of the most developed aborted pods had reached the same stage, which should therefore represents the final stage in seed abortion (FSSA). Under the experimental conditions mentioned by these authors, this stage was reached about twenty days after flowering, at the same time as pod 
elongation stopped (KATO et al., 1954). The growth curves obtained by SUETSUGU et al. (1962) indicated that the end of pod elongation and the beginning of the linear phase of dry matter accumulation in seeds occurred simultaneously. The FSSA should then coincide with these two events and correspond, for each pod, to a turning point between two phases : formation of seed number and of seed weights. Both phases are strictly sequential for an individual reproductive unit and may correspond to the two phases distinguished by DURE (1975) for seed growth and development in all legumes: cell division followed by cell growth.

The notion of a final stage in seed abortion suggested by these Japanese investigations has not received much attention to date. Yet it can be useful for agronomists. It enables us to characterize pod development in a way which is no longer arbitrary (for example a « $2 \mathrm{~cm}$-long pod» for soybean according to the scale of FEHR et al., 1971), but, rather, has some significance in respect of yield component development. The development cycle can thus be precisely divided into two phases : formation of seed number and formation of weight per seed. Only these two components are then taken into account. Using the notion of FSSA, it becomes obvious that the distinction between pod number and seed number per pod has no significance from a chronological point of view. Pod abortion and seed abortion both correspond to a cessation in embryo development during the period of pod elongation. In the first case, cessation occurs for all the seeds of a pod, in the second case, only some of them. The conventional distinction between pod abortion and seed abortion does not refer to chronological events but to the distribution of abortions.

The notion of FSSA may also be used to measure, before harvesting, the number of seeds which will be collected. When a pod continues to develop beyond the FSSA, the number of non-aborted seeds equals the number of seeds harvested. It becomes possible, then, to link directly, and not only statistically, the component « seed number » to the plant characteristics at the time of formation of this component. This can be useful to acquire a better knowledge of the laws that rule its formation.

The first aim of the present work is to determine if the notion of FSSA can be extended to other grain legume species, which is suggested by LINCK's observations (1961) on peas. Two pea cultivars (Pisum sativum L.) and four white lupin cultivars (Lupinus albus L.) were used for that purpose.

The second aim of this study was to look for a characterization of the FSSA, based on a more convenient criterion than the embryo or cotyledon development stage. SPAETH \& SINCLAIR (1984) demonstrated that in the soybean cultivar 'Chippewa 64' the beginning of the linear phase of dry matter accumulation in seeds corresponded to a seed weight of $15 \mathrm{mg}$ dry matter. These authors also utilized the silhouette method (observation within the pod through the translucent pod wall), in order to characterize by its length the stage reached by a seed.

These two criteria, seed weight and seed length, are first measured with seeds sampled at harvest. The interval between the maximum value for aborted seeds and the minimum value of non-aborted seeds represents an estimator of the value (X) after which seeds do not abort. Intravarietal and intervarietal variability of this estimator is studied. Secondly, length and dry weight of green seeds are measured indicating the reference length corresponding to the values $X$ observed at harvest. This can be used for identifying the FSSA on green seeds.

\section{MATERIALS AND METHODS}

\section{A. Values $\mathrm{X}$ for dry seeds}

\section{Seed samples}

Twenty six seed samples were analysed, among which 20 were of indeterminate soybean, 4 of white lupin and 2 of pea. The main characteristics of the studied cultivars and the origin of the samples are indicated in table 1. Samples originated either from field varietal trials conducted by the Stations d'Amélioration des Plantes in Montpellier and Dijon (soybean, Montpellier and Dijon), or from field or greenhouse agronomic trials conducted with several cultivars by the Stations d'Agronomie in Toulouse and in Dijon (soybean, Toulouse; white lupin and pea Dijon).

Most of the samples came from plots where cropping conditions (table 2) were close to those usually recommended in husbandry methods. For the soybean cultivar 'Hodgson', four samples from the same location (Toulouse, 1982), but grown under various conditions, were analysed (table 2). Mean seed productions per plant for each sample are given in table 2.

Plants were sampled at maturity. In the case of varietal trials, consecutive plants were sampled on the border of plots. In the case of field agronomic tests, plants were sampled either at random (soybean, Toulouse), or from a central area in the plot (lupin and pea, Dijon). Except for a few samples, the number of analysed plants was chosen in such a way as to obtain approximately one thousand collected seeds per sample (table 3 ), that is from 6 to 11 for soybean, 18 to 39 for lupin, 23 to 39 for pea. Gradients of the abortion rate or of the weight per seed with respect to the position of the pod on the plant have already been observed (FARRINGTON, 1976). In the present study, special pod position on the plant has not been considered. All seeds of a number of plants have been collected.

\section{Observations}

\section{a) Morphology}

Seeds were distributed into 3 classes according to their morphological aspects (fig. 1): ripe seeds represent the seeds usually harvested. They have a smooth seed coat and their shape is characteristic of the species (fig. 1C). They are always thick. Aborted their morphological aspects (fig. 1) : ripe seeds shape is different from that of ripe seeds (fig. 1A). Their colour is often darker. For some samples, we were led to take into account a third seed class we 
TABLE 1

Main characteristics of the cultivars studied; number of samples for each cultivar. Principales caractéristiques des variétés étudiées; nombre d'échantillons par variété.

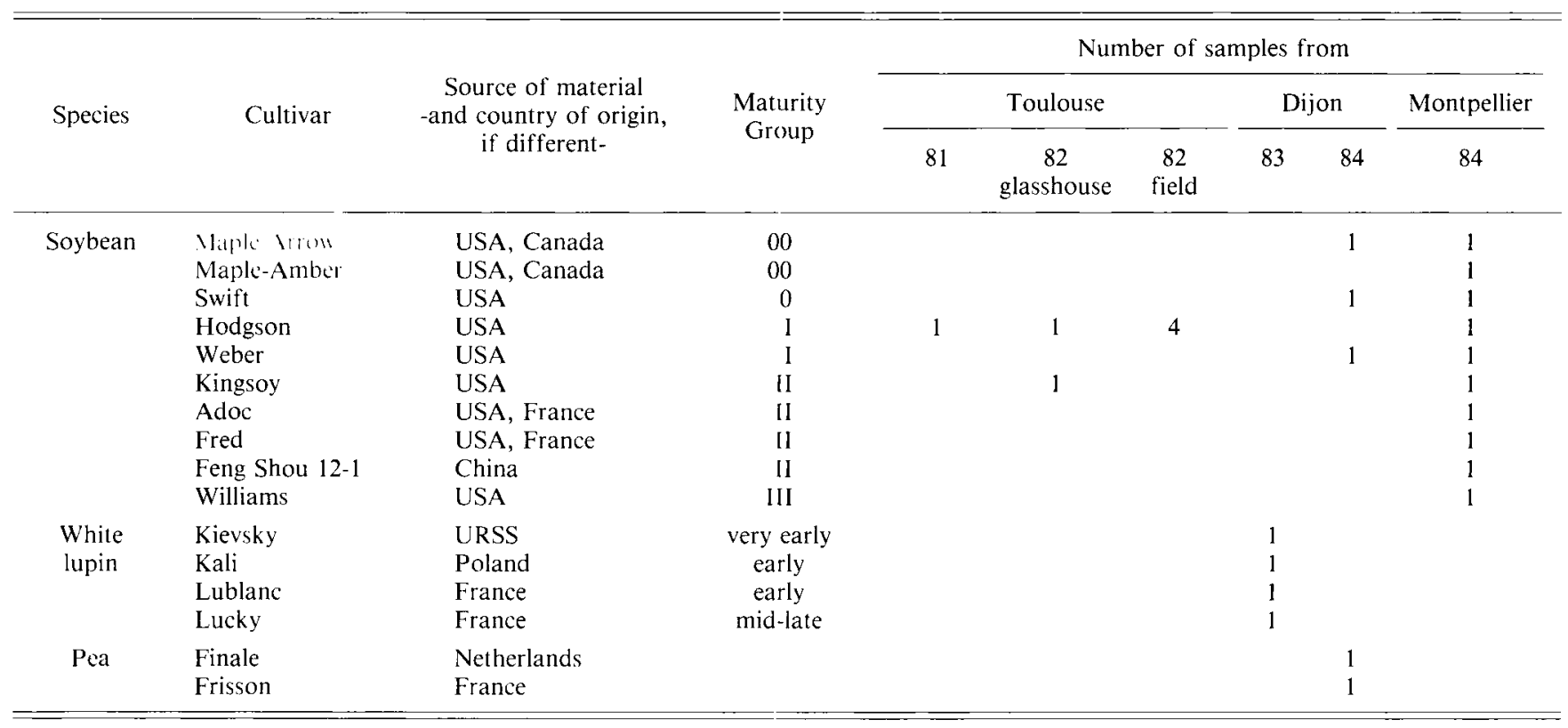

\section{TAB1.E 2}

Main characteristics of the crops from which seeds were harvested.

Principales caractéristiques des cultures d'où proviennem les èchanillons de grains.

Soybein cultivars: (A) Adoc, (Fe) Feng Shou 12-1, (F) Fred, (H) Hodgson, (K) Kingsoy, (M-Am) Maple-Amber, (M-Ar) Maple-Arrow', (S) Swift, (We) Weber, (Wi) Willians.

White lupin cultivars: (l.ub) L.ublanc, (Luc) Lucky, (Ka) Kali, (Ki) Kiersky. Pea cullivars: (Fi) Finale, (Fri) Frisson.

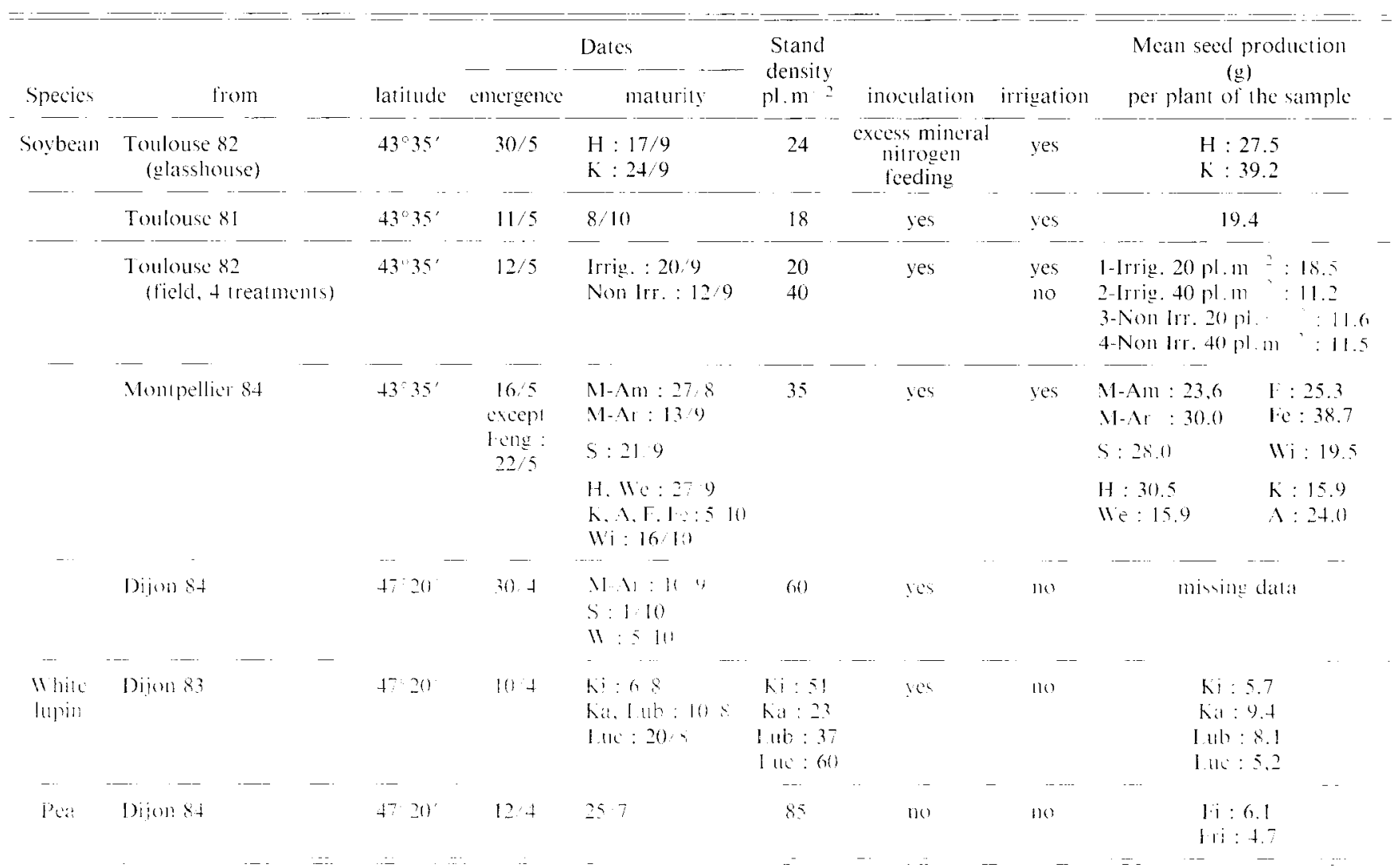




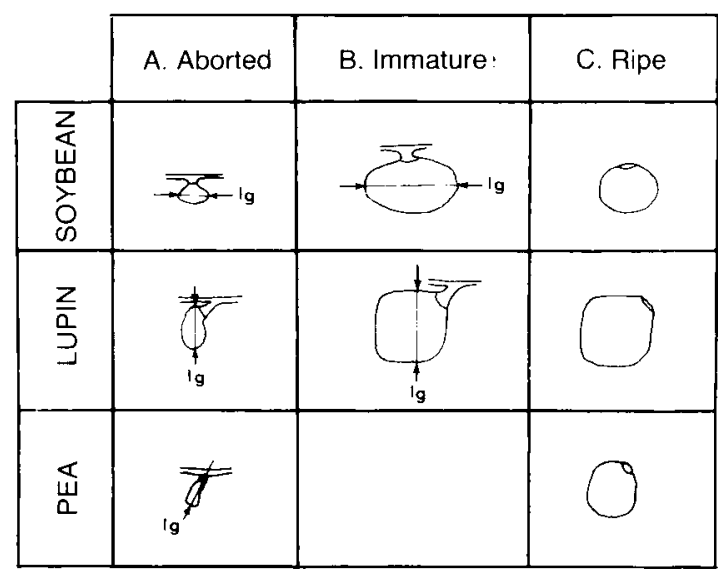

Figure 1

Seed shapes at maturity; $l g=$ length.

Morphologies de grains observables à la récolte ; lg = longueur.

called immature seeds. This class corresponds to seeds which have already undergone a great elongation of their cotyledons (fig. 1B) and which are not flat. In soybeans they are ovoid and dark-coloured, whereas ripe seeds are almost spherical and rather yellow. In white lupin, immature and ripe seeds have approximately the same shape, but the former are orangecoloured and the latter rather white. We did not find any immature seeds in pea. Immature seeds are seeds which have developed beyond the FSSA as defined b! KATO \& SAKAGUCHI (1954) and KATO el al. (1955), without however having reached full maturity.

\section{b) Length}

Individual aborted and immature seeds were measured. Ripe seeds were not measured because they change their shape during maturation, especially in soybeans (SUETSUGU et al., 1962). Therefore there was no purpose in comparing ripe seed length to aborted or immature seed length. Seed length was measured by putting seeds on graph paper. In the case of soybeans, the seed length is parallel to the pod elongation axis (fig. 1A). In the case of lupin it is perpendicular to it (fig. 1A). Pea seed length was measured from the hilum of the seed up to its distal end (fig. 1A) ; for some pea seeds, this did not represent their longest part, because growth is sometimes more important in the direction of pod elongation.

\section{c) Weight}

Dry matter weighings were carried out after oven drying for $24 \mathrm{~h}$ at $105^{\circ} \mathrm{C}$. Aborted and immature seeds were weighed individually. Ripe seeds were first weighed all together. Their mean weight was then calculated after counting the seeds. The smallest ripe seeds were weighed individually afterwards. For one of the samples (soybean 'Hodgson', Toulouse 1981), all ripe seeds were weighed individually, in order to draw the complete histogram presented in figure 2 .

\section{B. Reference lengths for green seeds}

Green seeds were sampled during the 1985 season at Dijon on plot borders of agronomic trials (lupin, cv. 'Lublanc' ; pea, cv. 'Finale' and 'Frisson') or varietal trials (soybean, cv. 'Maple-Arrow' and cv. 'Sito' of the maturity group 000). Seeds were classified by length (every other $\mathrm{mm}$ ). For each subsample ten seeds were oven dried $\left(24 \mathrm{~h}\right.$ at $\left.105^{\circ} \mathrm{C}\right)$ and ten other seeds were air dried $(72 \mathrm{~h})$. Afterwards their new length was measured and then they were weighed after a last oven drying. We put forward the hypothesis that the evolution of the dry weight of aborted seeds is negligible between time of abortion and harvest.

\section{RESULTS AND DISCUSSION}

The cumulative frequencies of aborted seeds, with respect to length (every other $\mathrm{mm}$ ) and weight (every $5 \mathrm{mg}$ ), as well as the maximum weight of aborted seeds and the minimum and mean weights of ripe seeds are summarized in tables 3 and 4 . Figure 2 illustrates what the histograms for seed weight and seed length look like on the basis of the sample with the highest percentage of immature seeds.

\section{A. Respective locations of the different seed populations on the weight and length histograms}

In most cases there was no overlapping of the weights of aborted seeds and of those of ripe seeds (table 4). Only three soybean samples made an exception to this rule : for cultivars 'Weber' (2 samples) and 'Fred' a ripe seed with a weight lower by a few milligrams than the biggest aborted seed (table 4).

No overlapping of aborted seed weight or length and immature seed weight or length was noted either. The results concerning immature seeds have not been reported because of the low seed count.

These results allow us to conclude that the notion of a FSSA can be applied to the three species studied. Weight or length criteria can be used to determine within each sample the point (value $\mathrm{X}$ ) after which the seeds do not abort.

\section{B. Variability of value $X$}

For both quantities measured, value $\mathrm{X}$ lies necessarily within the interval between the maximum value for aborted seeds and the minimum value for ripe or immature seeds. Consequently this interval is its estimator. A complete determination of this interval can only be carried out for seed weight (table 4). For the critcrion 'seed length', the minimum value for ripe seeds is not defined (see II-A-2). That for immature seeds is also in adequately defined because of their low count or non-existence. Therefore the variability of value $(\mathrm{X})$ with respect to seed weight was investigated. 
TABLE 3

Proportions of the different seed types and distribution of the lengths of aborted seeds. The percentages of aborted seeds corresponding to the reference size $(\%>95 \%)$ are underlined.

Proportions des différents types de grains et distribution des longueurs des grains avortés. Les pourcentages de grains avortés correspondant aux valeurs de référence (\% > $95 \%$ ) sont soulignés.

\begin{tabular}{|c|c|c|c|c|c|c|c|c|c|c|c|c|c|}
\hline \multirow{2}{*}{\multicolumn{3}{|c|}{ Sample }} & \multirow{3}{*}{$\begin{array}{c}\text { Total } \\
\text { number } \\
\text { of } \\
\text { seeds }\end{array}$} & \multirow{2}{*}{\multicolumn{3}{|c|}{$\%$ lotal seeds }} & \multicolumn{7}{|c|}{$\omega_{0}$ aborted seeds } \\
\hline & & & & & & & & & \multicolumn{4}{|c|}{ 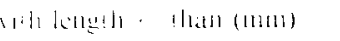 } & \multirow[b]{2}{*}{10} \\
\hline Soybean & Cultivar & from & & aborted & immature & ripe & $\begin{array}{c}- \\
4\end{array}$ & 5 & $\overline{6}$ & 7 & 8 & 9 & \\
\hline \multirow[t]{20}{*}{ Species } & Maple-Arrow & Montpellier 84 & 1263 & 6.9 & 0.1 & 93.0 & 17.2 & 59.7 & 94.2 & 100 & & & \\
\hline & & Dijon 84 & 1298 & 24.6 & $\|$ & 75.4 & 22.6 & 52.7 & 87.4 & $\overline{98.5}$ & 100 & & \\
\hline & Swift & Montpellier 84 & 1452 & 7.4 & 0.9 & 91.7 & 29.0 & 82.3 & 100 & & & & \\
\hline & & Dijon 84 & 1402 & 9.3 & 0 & 90.7 & 22.3 & 84.7 & 98.5 & 100 & & & \\
\hline & Weber & Montpellier 84 & 1426 & 7.3 & 0.4 & 92.3 & 30.8 & 95.2 & 100 & & & & \\
\hline & & Dijon 84 & 1675 & 10.2 & 0 & 89.8 & 44.4 & $\overline{97.2}$ & 100 & & & & \\
\hline & Hodgson & 1. 82 (glassh.) & 1122 & 17.8 & 0 & 82.2 & 25.2 & $\overline{70.5}$ & 91.0 & 100 & & & \\
\hline & & loulouse 81 & 1142 & 9.5 & 2.6 & 87.9 & 38.9 & 81.4 & 100 & & & & \\
\hline & & Toulouse 82-1 & 1135 & 14.7 & 0.4 & 84.9 & 19.2 & 70.1 & $\overline{99.4}$ & 100 & & & \\
\hline & & Toulouse $82-2$ & 634 & 12.6 & 0.2 & 87.2 & 38.3 & 74.1 & $\overline{95.1}$ & 100 & & & \\
\hline & & Toulouse $82-3$ & 676 & 10.4 & 0.6 & 89.0 & 42.8 & 89.9 & 100 & & & & \\
\hline & & Toulouse $82-4$ & 614 & 11.1 & 0 & 88.9 & 33.9 & 79.5 & 92.7 & 100 & & & \\
\hline & & Montpellier 84 & 1233 & 6.8 & 0.6 & 92.6 & 33.2 & 80.8 & 95.0 & 100 & & & \\
\hline & Kingsoy & 1. $k_{2}$ (g) adshor) & 1016 & 18.4 & 0.2 & 81.4 & 53.7 & 92.5 & $\overline{100}$ & & & & \\
\hline & & Nomepellier sit & 1158 & 6.0 & 0.9 & 93.1 & 49.3 & 90.1 & $\overline{100}$ & & & & \\
\hline & Maple-Amber & Montpellier 84 & 1207 & 5.7 & 0.1 & 94.2 & 20.3 & 82.6 & $\overline{98.5}$ & 100 & & & \\
\hline & Fred & Montpellier 84 & 1434 & 4.0 & 0.4 & 95.6 & 38.0 & 81.1 & 100 & & & & \\
\hline & Adoc & Montpellier 84 & 1169 & 10.8 & 1.6 & 88.6 & 25.2 & 70.9 & $\overline{99.2}$ & 100 & & & \\
\hline & Feng Shou 12-1 & Montpellier 84 & 1486 & 5.1 & 0.2 & 94.7 & 47.3 & 73.6 & $\overline{98.6}$ & 100 & & & \\
\hline & Williams & Montpellier 84 & 1242 & 10.3 & 0 & 89.7 & 39.8 & 75.8 & 96.1 & 100 & & & \\
\hline \multirow{6}{*}{$\begin{array}{l}\text { White } \\
\text { lupin }\end{array}$} & Kievsky & Dijon 83 & 784 & 14.7 & 0.4 & 84.9 & 86.9 & 99.1 & 100 & & & & \\
\hline & Kali & Dijon 83 & 850 & 22.2 & 0.6 & 77.2 & 74.1 & 92.1 & 95.8 & 97.4 & 100 & & \\
\hline & Lublanc & Dijon 83 & 737 & 22.5 & 0 & 77.5 & 85.7 & 95.7 & 97.2 & 98.8 & 99.0 & 99.2 & 100 \\
\hline & Lucky & Dijon 83 & 668 & 25.3 & 0.3 & 74.4 & 81.8 & 97.1 & 98.3 & 99.5 & 100 & & \\
\hline & & & & & & & & \multicolumn{5}{|c|}{ whkng:h. !han (nm) } & \\
\hline & & & & & & & 2 & 3 & 4 & 5 & & & \\
\hline \multirow[t]{2}{*}{ Pea } & Finale & Dijon 84 & 904 & 37.9 & 0 & 62.1 & 9.0 & 54.2 & $\underline{96.8}$ & 100 & & & \\
\hline & Frisson & Dijon 84 & 1381 & 35.6 & 0 & 64.4 & 35.4 & 97.6 & 100 & & & & \\
\hline
\end{tabular}

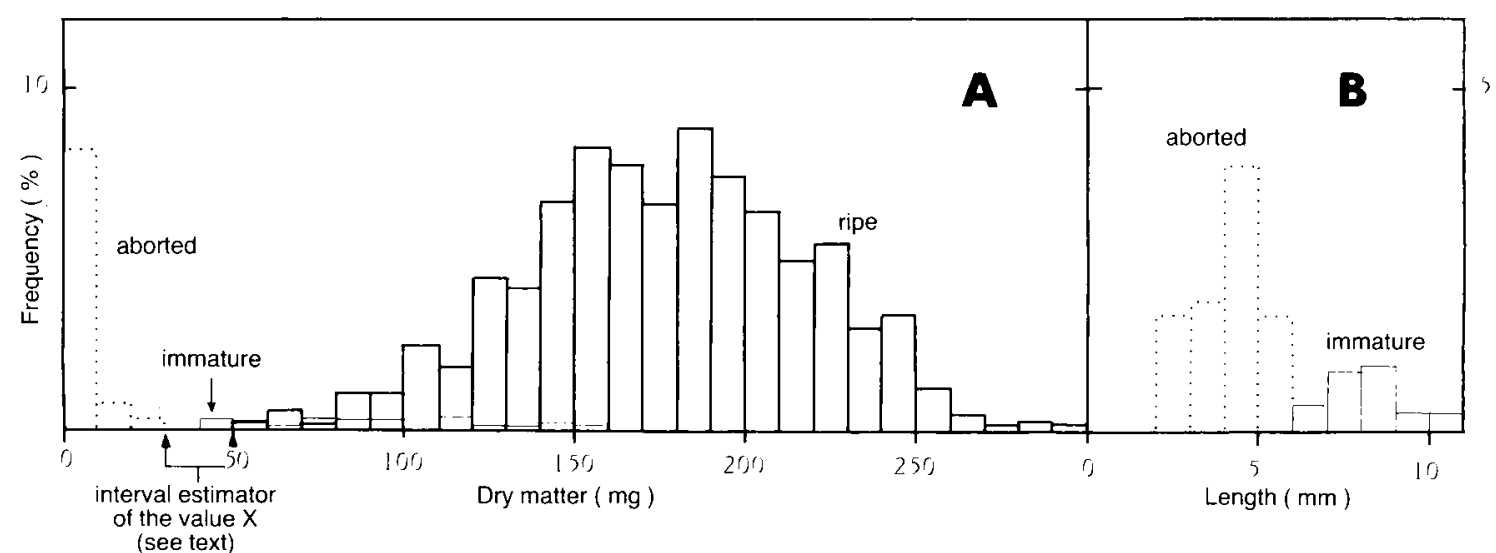

Figure 2

Histograms of (A) seed weight and (B) seed length; $c v$. 'Hodgson', Toulouse 1981. Ripe seed lengths are not represented (see II - Material and methods).

\section{Intravarietal variability}

It happened in some cases that the estimating intervals of value $X$ determined for samples of the same cultivar were completely unrelated. The greatest deviation between intervals was thus obtained for the
Histogrammes de poids (A) et de longueur (B) des grains, pour l'échantillon de la variété « Hodgson » en provenance de Toulouse, année 1981. Les longueurs des grains mûrs ne sont pas représentées (cf. II - Matériel et méthodes).

samples 'greenhouse, Toulouse, 1982' and 'Toulouse 1982-2' of the soybean cultivar 'Hodgson'. The minimum weight of the ripe seeds in the former was lower by $19 \mathrm{mg}$ than the maximum weight of the aborted seeds of the latter. As value $\mathrm{X}$ lies necessarily 
TABLE 4

Distribution of the dry weights of aborted seeds, maximum dry weight of aborted seeds, minimum and mean weights of ripe seeds.

The percentages of aborted seeds corresponding to reference values ( $\%>95 \%$ ) are underlined.

Distribution des poids secs des grains avortés, poids maximal des grains avortés, poids minimal et moyen des grains mûrs. Les pourcentages de grains avortés correspondant aux valeurs de référence (\%>95\%) sont soulignés.

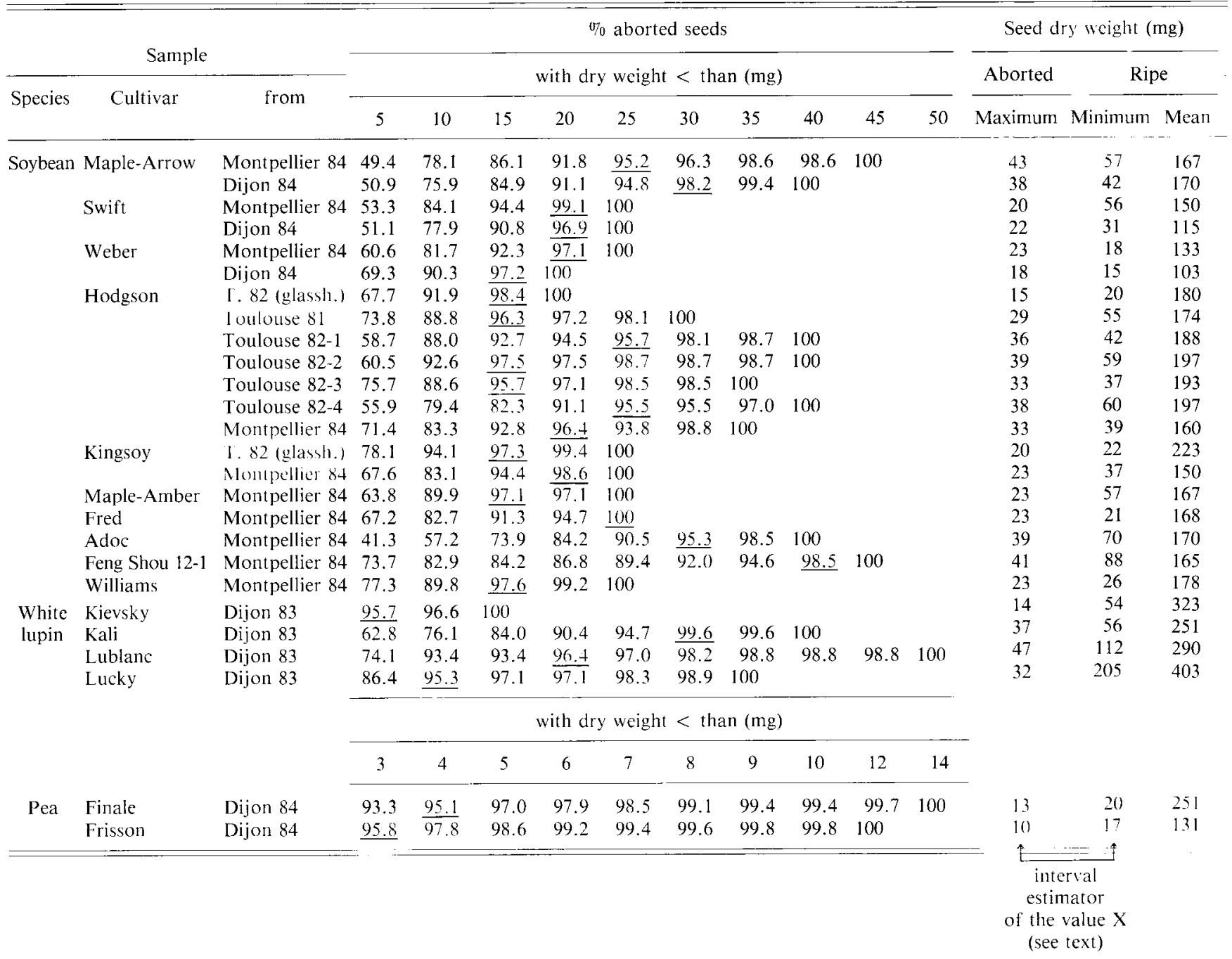

within the interval, when there is no overlap between the intervals of two samples, it means that their values are different.

The maximum length of aborted seeds varied less than their maximum weight. It only varied in cultivar 'Hodgson', and only by $1 \mathrm{~mm}$. No relationship between maximum length and maximum weight could be noted (tables 3 and 4 ).

\section{Intervarietal variability}

The estimating intervals for cultivars of the same origin were sometimes totally unrelated : this was the case for cultivars 'Williams' and 'Feng Shou' originating from Montpellier 1984. In other cases it was impossible to distinguish between cultivars, because their intervals overlapped. No contradiction in the classification of cultivars from one location to another was observed (table 4).

Sometimes (eg. soybean-Dijon 1984) the classification of cultivars by their value $X$ corresponded with their classification by the mean weight of ripe seeds and someinies not (eg. soybean Montpellior 1984).
GULDAN \& BRUN (1985) provided evidence that the variation of mean weights per seed among soybean cultivars was linked to differences in cotyledon cell numbers. The end of the formation of the cotyledon cell number approximately coincides with the FSSA. The seed weight could thus have been dependent on the cotyledon cell number from that time.

The maximum length of aborted seeds, between cultivars as well as within the same cultivar, varied less than their maximum weight. Its variation range reached $2 \mathrm{~mm}$ in soybean, $4 \mathrm{~mm}$ in lupin and $1 \mathrm{~mm}$ in pea.

\section{Selection of a reference for the final stage in seed abortion}

\section{Reference values for dry seeds}

In both weight and length histograms, the last columns of aborted seed populations usually showed very low frequencies (tables 3 and 4 ). Under such conditions, it may be appropriate not to use a direct 
estimator of value $\mathrm{X}$ as a reference. Rather a lower value more representative of the upper limit of most aborted seeds could be used. Numbers of harvestable seeds measured on the basis of such a reference size would be slightly overestimated relative to numbers of seeds harvested later. Nervertheless, the reference stage would be closer to the main period of seed abortion. Also, determining such a reference size was less delicate from the point of view of sampling than estimating value $X$. We therefore suggest that the reference size should be the first value for which the cumulative frequency of aborted seeds is at least $95 \%$. In tables 3 and 4 , a line drawn under the percentages equal to or higher than $95 \%$ focuses attention on the reference sizes, with a precision of $5 \mathrm{mg}$ for weight and $1 \mathrm{~mm}$ for length. In all cases, reference lengths varied less than reference weights.

\section{Reference values for green seeds}

Length was a more convenient criterion than weight to determine the FSSA during the crop's growth. SPAETH \& SINCLAIR silhouette method (1984) for soybeans could also be used for lupin and pea. To find the values for green seeds that corresponded with those of dry seeds, we used two relationships :

(1) that between green seed length and dry seed weight,

or (2) that between green seed length and dry seed length.

For each species, results were similar according to the variety and the method of drying. Values increased continuously except for relationship (2) in soybean, which showed a plateau : 7 to $12 \mathrm{~mm}$ long seeds all retract to between 5 and $6 \mathrm{~mm}$. Therefore for this species, reference lengths for green seeds have been established only with relationship (1) : $9-12 \mathrm{~mm}$ for $15-40 \mathrm{mg}$, which is the range of the reference weight for the 20 samples. For white lupin and pea, results obtained with relationships (1) or (2) were similar : (1) $6-12 \mathrm{~mm}$ for $5-30 \mathrm{mg}$ and (2) $7-9 \mathrm{~mm}$ for $5-6 \mathrm{~mm}$ in white lupin ; (1) $4-5.5 \mathrm{~mm}$ for $3-4 \mathrm{mg}$, and (2) $4-5.5 \mathrm{~mm}$ for $3-4 \mathrm{~mm}$ in pea.

In soybean, 13 out of 20 samples had a reference weight lower than or equal to $20 \mathrm{mg}$ whilst 17 out of 20 had one lower than or cqual to $25 \mathrm{mg}$. Green seed lengths corresponding to 20 and $25 \mathrm{mg}$ were 10 and $11 \mathrm{~mm}$. If one of these lengths was selected for all samples, the maximum error would be $2 \mathrm{~mm}$. According to Suetsugu et al. (1962), a $2 \mathrm{~mm}$ difference corresponds to a maximum delay of 4-5 days in determining the FSSA stage, which is a relatively short time for agronomic studies. We therefore believe that a length of $11 \mathrm{~mm}$ can be selected for all soybean varieties. The growth dynamics reported by SuETSUGU et al. (1962) show that a $11 \mathrm{~mm}$ seed length is reached about ten days before the termination of seed elongation (about $14 \mathrm{~mm}$ ) and 4-5 days after the end of pod elongation. This coincides with the FSSA as can be defined from the work of KATO et al. (1954). Hence, our observations approximate those of KATO et al. on Japanese varieties.

In lupin and pea, a larger number of samples needs to be analyzed before any reference length can be selected for the species. This length, however, is probably in the range $7-9 \mathrm{~mm}$ for white lupin and close to 4-5 $\mathrm{mm}$ for pea.

\section{Notation of the final stage in seed abortion}

Among seeds from the same pod, there is a development gradient (KATO et al., 1954 ; HEDLEY \& AMBROSE, 1981). For early stages of soybean pod development, this gradient represents the order of fertilization (KATO et al., 1954). It increases chiefly because of seeds which eventually abort (HEDLEY \& AMBROSE, 1981), but remains low for seeds which do not (SPAETH \& SINCLAIR, 1984). To characterize the stage of development of a pod, one may consider that the pod has reached the FSSA as soon as at least one seed has reached the reference length.

For the three species studied, the differences in flowering time implies that the FSSA was not reached at the same time by all pods. It is therefore necessary to define the FSSA in the whole plant in relation to the morphogenetic type of each species. In indeterminate soybean and in pea, this notation could be derived from proposals by SPAETH \& SINCLAIR (1984) and SINCLAIR (1984) : according to the number of the topmost node having at least one pod beyond the FSSA.

The FSSA coincided with the cessation of pod elongation, that is, in soybean, shortly before the pod has reached its maximum weight (SUETSEGU et al., 1962) and with the onset of seed-filling (Section I). As a result, the time range within which the FSSA is passed through in the whole plant, was represented by two particular dots on the growth curves of pods and seeds. When the earliest plant pod passed through the FSSA, seed-filling started in the whole plant. This represented the onset of the seed growth curve. When the latest plant pod passed through this final stage, all pods had stopped elongation and had nearly reached their maximum weight. This date thus roughly coincided with maximum pod weight.

In soybean, these dates could be seen in relation to the scale of development by FEHR et al. (1971). According to HANWAY \& WEBER (1971), the onset of seed growth and the termination of pod growth coincide with stages $6-7$ and stage 8 respectively of the scale designed by KALTON et al. (1949), i.e. with stages R3-R4 and R5 respectively of the scale by FEHR et al. (1971). For this species, the seed number can be regarded as definitively set at stage R5 of the scale by FEHR et al. (1971).

\section{CONCLUSION}

For the 20 soybean samples, 4 lupin samples and 2 pea samples analyzed in this study, the notion of a final stage in seed abortion was of general validity. The length representing the upper limit of at least $95 \%$ of aborted seeds was conventionally selected to be of the reference size for the dry seeds sampled at harvest. The lengths of green seeds corresponding to these values were determined and could be used as reference lengths for identifying the FSSA during crop growth. For soybean a $11 \mathrm{~mm}$ length could be 
regarded as adequate for the entire species. For white lupin and pea, variation ranges for reference lengths were $6-12 \mathrm{~mm}$ and $4-5.5 \mathrm{~mm}$ respectively.

Reçu le 22 mars 1985. Accepté le 7 décembre 1985.

\section{ACKNOWLEDGMENTS}

We thank $\mathrm{Mr}$ VIDAI (I.N.R.A., Montpellier-Melgueil) and MT DıRFY (I.N.R.A., Dijon-Bretenières) for kindly supplying a number of soybean samples, and Mrs Do Bs (I.N.A.. Paris(irignon) for her help in statistics.

\section{REFERENCES}

Dure L. S., 1975. Seed formation. Annu. Rev. Plant Physiol., 26, 259-278.

Farrington P., 1976. Fruit development and associated changes in the distribution of dry weight and nitrogen in Lupinus angustifolius cv. Uniharvest and L. cosentinii selection CB 12. Aust. J. Exp. Agric. and Anim. Husb., 16, 387-393.

Fehr W. R., Caviness C. E., Burmood D. T., Pennington J. S., 1971. Stage of development descriptions for soybeans, Glycine max (L.) Merril. Crop Sci., 11, 929-931.

Guldan S., Brun W. A., 1985. Relationship of cotyledon cell number and seed respiration to soybean seed growth. Crop Sci., 25, 815819.

Hanway J. J., Weber C. R., 1971. Dry matter accumulation in soybean (Glycine $\max$ (L.) Merril) as influenced by N, P and K fertilization. Agron. J., 63, 263-266.

Hedley C. L., Ambrose M. J., 1981. Designing « leafless » plants for improving yields of the dried pea crop. Adv. Agron., 34, 225277.

Kalton R. R., Weber C. R., Eldredge J. C., 1949. The effect of injury simulating hail damage to soybeans. Iowa Agr. Exp. Stn. Res. Bull., 359.
Kato I., Sakaguchi S., 1954. Studies on the mechanism of occurrence of abortive grains and their prevention in soybeans Glycine max M. Tokai-kinki Nat. Agr. Exp. Stn Bull., 1, 115-132.

Kato, I., Sakaguchi S., Naito Y., 1954. Development of flower parts and seed in the soybean plant, Glycine max M. Tokai-kinki Nat. Agr. Exp. Sta. Bull., 1, 96-114.

Kato I., Sakaguchi S., Naito Y., 1955. Anatomical observations on fallen buds flowers and pods of soybean, Glycine max M. Tokaikinki Nat. Agr. Exp. Sta. Bull., 2, 159-168.

Linck A. J., 1961. The morphological development of the fruit of Pisum sativum, var. Alaska. Phytomorphology, 11, 79-84.

Sinclair T. R., 1984. Cessation of leaf emergence in indeterminate soybeans. Crop Sci., 24, 483-486.

Spaeth S. C., Sinclair T. R., 1984. Soybean seed growth. I Timing of growth of individual seeds. Agron. J., 76, 123-127.

Suetsugu I., Anaguchi I., Saito K., Kumano S., 1962. Developmental process of the root and top organs in soybean varieties. Hokuriku Agr. Exp. Stn. Bull., 3, 89-96. 